\title{
Reprezentace muslimské ženy $v$ populární literatuře a její vliv na českou čtenářskou veřejnost
}

\author{
Eva Čermáková - Lenka Linhartová - Daniel Topinka \\ SocioFactor s.r.o., Daliborova 631, 70900 Ostrava - Mariánské Hory \\ Do redakce doručeno 20. října 2014; k publikaci přijato 17. března 2015
}

Tento text vznikl v rámci projektu „Islám v ČR: etablování muslimů ve veřejném prostoru“ (VG20132015113).

\author{
THE REPRESENTATION OF MUSLIM WOMAN IN THE POPULAR LITERATURE AND ITS IMPACT \\ ON THE CZECH PUBLIC
}

\begin{abstract}
The literary market in the Czech republic was gutted with a specific kind of so called muslim women novels during the past decades. This genre became enormly popular, particularly after the tragedy of $9 / 112001$. Typicaly, the stories depict the women as a victims of cruel patriarchal system of muslim countries and are reproduced in many variations. The popularity of such books attributes to creation and/ or confirmation of prejustices against muslim cultures as a whole. The study focusses on the impact of muslim women novels and memoirs on czech public, via analysis of reder's comments left on the czech reader server www.databazeknih.cz.
\end{abstract}

KEY WORDS orientalism; muslim woman; women novels; memoirs; islamophoby

ABSTRAKT Literární trh $\mathrm{v}$ České republice byl v posledních dekádách doslova zavalen specifickým typem tzv. ženských románů, zaměřených na osudy žen v prostředí muslimských kultur. Tento žánr zaznamenal enormní popularitu zejména po tragických událostech v USA z 11. 9. 2001. Stereotypní příběhy vykreslující ženu jako obět patriarchálního systému v islámských zemích se reprodukují v početných variacích a jejich popularita $v$ českém prostředí napomáhá $\mathrm{k}$ tvorbě či potvrzení předsudků vůči kulturám muslimských zemí. Studie se zaměřuje na dopad těchto románů na české čtenářky a čtenáře prostřednictvím rozboru komentářů zanechaných na čtenářském serveru www.databazeknih.cz.

KLÍČOVÁ SLOVA orientalismus; muslimské ženy; ženské romány; memoáry; islamofobie

\section{ÚVOD}

V českém prostředí představují muslimové poměrně nečetnou menšinu. Nedostatek osobní zkušenosti s muslimy je u většiny Čechů nahrazen zprostředkovanými obrazy islámu a muslimů předkládaných médii, které prezentují především problematické stránky tohoto odlišného světa. Jedním z faktorů, podílejícím se na formování náhledu české populace na islámské země, jsou ženské romány z orientálního / islámského prostředí. Typicky se jedná o produkci označovanou jako memoáry. Tyto knihy staví na autenticitě a individuální zkušenosti dotčených žen, které přežily většinou těžká trau- mata (útěk od násilnického manžela či rodiny, přežití „vraždy ze cti“, útisk režimu a podobně). V českém prostředí dosud neproběhla dostatečná reflexe tohoto fenoménu, ani ze strany publicistů, ani ze strany odborníků. Vliv těchto románů a memoárů na širokou veřejnost i jejich význam jako významného politika a (sebe)orientalizujícího média byl však diskutován v mnoha „západních“ i islámských odborných kruzích a je zřejmé, že česká společnost netvoří v tomto př́ípadě výjimku. Jedním ze způsobů poznání vlivu tohoto žánru na české čtenářky / čtenáře je analýza komentářù $\mathrm{k}$ vybraným dílům, zveřjněných na čtenářském webovém serveru. Výhodou tohoto postupu je přístup $\mathrm{k}$ bezprostřednímu a výstižnému vyjád- 

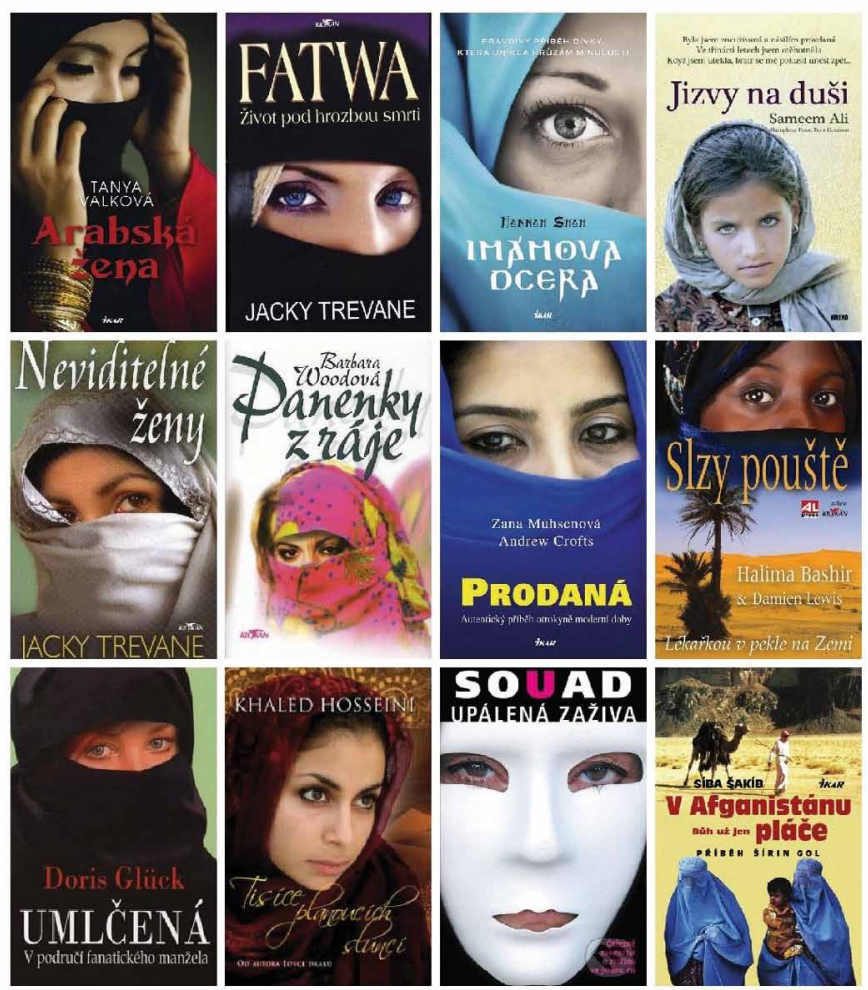

Obr. 1. Ukázka sugestivních přebalů knih věnovaných osudům islámských žen. Návrh ilustrace: Tomáš Janků.

ření zážitku $\mathrm{z}$ četby popsané (většinou) několika málo větami. Vycházíme z předpokladu, že relativně stručný charakter komentářů vede přispěvovatele $\mathrm{k}$ tomu, že se zaměří na nejsilnější a nejvýraznější dojem $\mathrm{z}$ četby. Za nevýhodu tohoto př́stupu lze považovat anonymitu přispěvatelů a jistý samo výběr až anketního rázu, což znamená, že přispívají jen ti, kdo chtějí a jejichž pohnutky není možné analyzovat. Komentáře byly zpracovány metodou otevřeného kódování $\mathrm{v}$ prostředí programu Atlas.ti.

\section{MUSLIMSKÁ ŽENA JAKO (SEBE)ORIENTALIZUJÍCÍ KONSTRUKCE}

Od prvních střetů křestanského „Západu“ a islámského světa se setkáváme s vykonstruovanými tradovanými obrazy žen muslimek. Postupnou proměnu od mocných žen „obryní“ raného středověku až po současné reprezentace muslimských žen jako pasivních obětí svých rodin i státních režimů popisuje arabsko-americká autorka Mohja Khaf (1999).

Svět středověkého „Západu“ vnímal muslimy především skrze údiv a rozhořčení, jak vyspělá a mocná kultura může vzniknout a existovat mimo hranice křestanského světa. Tento úspěch „nevěřících“ byl přičítán technologické vyspělosti a určitým domnělým magickým schopnostem. Ve středověkých „západních“ pramenech vystupuje muslimská žena poměrně řídce. Její percepce a reprezentace však tvoří analogii k vnímání islámského světa: muslimská žena jako královna nebo vysoce postavená žena obdařená mocí nad osudem křestanských hrdinů, „hrozivý a mocný ženský činitel hrozivého a mocného soupeře" (Kahf 1999, s. 71). Muslimská žena raného středověku postrádá charakteristiky jako závoj, nebo vyloučení $z$ veřejného života, což jsou typické rysy pozdějších prezentací. Zahalené chodily ve stř̌edověku hojně i Evropanky, nešlo tedy o exotický rys hodný zvláštní pozornosti. Díky politickým a společenským transformacím během renesance se proměnila i percepce muslimských žen. Pozdní středověk a zejména koloniální éra představuje muslimské ženy stále častěji jako postavy se zdůrazněnou sexuální stránkou. Od obrazů prostopášnic a harémových konkubín se reprezentace $\mathrm{v}$ průběhu devatenáctého století mění na nám již známý stereotyp viktimizované ženy trpící v barbarské patriarchální společnosti. Právě takové vykreslení utlačovaných žen v „zaostalých kulturách“ tvořilo významný ideologický základ, který v důsledku opravňoval intervence koloniálních mocností (Zine 2002, s. 4). „Bílý muži zachraňují hnědé ženy před hnědými muži“ jak lapidárně a výstižně poznamenává Gayatri Spivak (Spivak cit. In: Pazargadi 2010).

Bylo by ovšem mylné, domnívat se, že stereotypizace pohledů na muslimské ženy je pouze dílem Západu. Značná část produkce pochází převážně z per muslimských autorek, jejichž tvorba je často i formou určité terapie, která má napomoci ženě vyrovnat se s extrémně traumatickými zážitky války, migrace nebo rodinného násilí (Fotouhi 2012, s. 27). Tato motivace, jakkoliv patrně stála na začátku „boomu“ tohoto žánru po roce 2001 a bezpochyby je zastoupena podnes, není ovšem motivací jedinou. Jak dokazuje několik případů ze zahraničí, za memoáry se vydává i tvorba více či méně smyšlená. Na nejrůznější diskrepance a nesoulad ve skutečných životních datech autorek, reálií popisovaných zemí a jejich memoárovou podobou poukázali investigativní novináři například u knih Zakázaná láska (autorky Normy Khouri) a Upálená zaživa (autorky Souad); (blíže viz Jelodar 2014, Pazargadi 2010). Pozměněné nebo vymyšlené příběhy, či přímo podvrhy, vydávané za autentické príběhy masově konzumované západní čtenářskou veřejností, poukazují na enormní atraktivitu a význam tohoto žánru. Jedním $\mathrm{z}$ důvodů této tvorby je i značná poptávka ze strany západní veřejnosti, která tímto způsobem uspokojuje svoji zvědavost až voyeurství týkající se exotických kultur (Huggan 2001). Ekonomický aspekt literatury o muslimských ženách představuje významnou motivaci produkce a šíření tohoto žánru.

\section{MUSLIMSKÁ ŽENA JAKO KOMODITA}

Hlad po „autentických“ příbězích muslimských žen zesílil v kontextu tragických událostí z 11. září 2001. Romány reprodukující negativní stereotypy muslimských mužů se zejména v Americe staly bestsellery (Pazargadi 2010, 3). Čtenáři k tomuto žánru přistupují s určitým očekáváním, které je obvykle naplněno.

Typická produkce „ženské muslimské literatury“ se více či méně drží několika klišé: typicky jde o př́iběh mladé ženy, která se stává obětí v důsledku neuposlechnutí prríkazů, vze- 
pření se tradici a požadavkům rodiny a jsou za to potrestány. Aktérky bud' pochází přímo z islámské země, kde se stávají obětí režimu, manžela, nebo vlastní rodiny, případně pochází z Evropy (nebo obecně západního světa), př́ípadně jde o zástupce tzv. "druhé generace“ (tedy děti rodičů muslimů, vyrůstající v Evropě), kteří jsou nuceni odejít do země původu rodičů a vdát se za muslimy a stávají se opět obětmi patriarchální islámské společnosti a nové rodiny. Islámské země zde vystupují jako past, jako místo útlaku a nebezpečí, „Západ“ se naopak stává vysněnou zemí záchrany či přímo „sekulárním nebem" (Jelodar et al. 2014 s. 215).

Jakousi všeobecně srozumitelnou „obchodní značkou“ tohoto žánru se stává obálka knihy, která produkt de facto prodává (obr. 1). V drtivé většině případů znázorňuje exotickou zahalenou ženu, často jen s viditelnýma očima, sugestivně se upírajícími na čtenářku / čtenáře. Jak se domnívá S. Fotouhi, obálky tohoto typu mají představovat pro čtenáře provokující výzvu odhalit tento tajemný a západu ukrytý svět. Vyvolává představu jedinečného životního prŕběhu, který se zračí v očích ženy zahalené tradičním muslimským zpơsobem (Fotouhi 2012, s. 29). Rovněž často dramatické názvy knih vychází vstřric očekávání svých čtenářek / čtenářù, v české produkci např́klad: Fatwa: život pod hrozbou smrti; Prodaná; Umlčená. Tyto „paratexty“, tedy tituly, obálky a upoutávky představují jakousi esenci orientalizujícího pohledu na život muslimských žen, pomocí kterých dochází k dalšímu šíření a upevňování stereotypů (Jelodar et al. 2013).

Muslimská žena, respektive její tragický životní příběh, se tak stává doslova obchodovatelnou komoditou. Poptávka trhu vyprodukovala jakousi ideální uměle vykonstruovanou postavu „Muslimwoman“ (Cooke in: Gökariksel - McLarney, s. 5), bytost trpící a volající po záchraně. Podstatnější diferenciace muslimské ženy na základě geografické př́slušnosti, etnických či trrídních kontextů, které vytvárí celé spektrum různých způsobů „bytí ženou“ v muslimském světě (Janků 2013) zůstávají prakticky zcela opomenuty.

\section{MUSLIMSKÁ ŽENA JAKO POLITIKUM}

Jak bylo již zmíněno výše, západní pohled na muslimskou ženu vždy nějakým zpơsobem reflektoval kulturně-politickou situaci, ve které se oba „světy“ zrovna nacházely. Dnešní stav netvoří $\mathrm{v}$ tomto ohledu žádnou výjimku a stejně jako $\mathrm{v}$ koloniální éře reprodukuje obrazy „muslimských žen $\mathrm{v}$ nouzi“ (Zine, 2002, s. 3). Podle Whitelocka, představují právě tyto bestsellery a memoáry muslimských žen velmi zneužitelný materiál pro propagandu a šíření islamofobie. Mluví přímo o „soft weapons“ pomocí nichž se války vedou v dnešní době: „V moderních demokratických společnostech se propaganda již nevede prostřednictvím násilného a presvědčovacího zneuživání idejí, ale jemnou manipulací s názory a emocemi veřejnosti..." (Whitelock 2007, s 3). Obraz agresora je potřeba vyjádřit $\mathrm{v}$ co nejhorším světle, aby byl př́padný útok veřejností podpořen a byl vnímán jako akt záchrany pro utlačovanou část populace.

\section{VLIV MUSLIMSKÝCH ŽENSKÝCH ROMÁNŮ NA ČESKOU VEŘEJNOST NA ZÁKLADĚ ANALÝZY KOMENTÁŘ Ů}

Pro rozbor bylo vybráno 26 knih s největším počtem komentář̉. Celkově bylo analyzováno 398 komentářů (nejnižší počet komentářů $\mathrm{k}$ jedné knize byl 4 , nejvyšší počet komentářu u knihy byl 82 př́spěvků). Komentáře byly čerpány ze severu databazeknih.cz, který umožňuje vkládat pod jednotlivé tituly názory čtenářů / čtenářek, kdy jednotliví přispěvatelé / př́ispěvatelky nemohou reagovat na příspěvky ostatních.

Příběhy žen vyvolávají v komentujících emoce: smutek, slzy, zlost, strach, hrůzu, mrazení. Jsou jimi hodnoceny jako silné, čtivé a působivé - na tom se podílí často jejich autentičnost a pravdivost. „Jedna $z$ nejlepších knih, co jsem kdy četla!!! Četla jsem ji jedním dechem a konec knihy jsem probrečela..."

Komentující s hlavními postavami soucítí a zároveň je obdivují. Na jednu stranu jsou postavy obětmi, příběhy jsou silně viktimizační a komentáře čtenářů a čtenářek toto potvrzují. $\mathrm{Na}$ druhou stranu se v komentárích hlavní postavy heroizují, oceňuje se jejich síla přežít utrpení a promluvit, podat o tomto utrpení svědectví - „seznámit svět s těmito hrůzami“.

Ženy se v komentárích ztotožňují s ženskými postavami, prožívají s nimi jejich př́iběhy, představují si samy sebe na jejich místě, „hltají príběhy po stránkách“. Jedná se o fascinující žánr, který upoutává pozornost.

Čtenářky a čtenáři ve svých komentárích vyzdvihují, že se díky knize dozvěděly zajímavé informace o životě $\mathrm{v}$ dané zemi (městě / vesnici), nahlédly do struktury tamní rodiny, poznaly mentalitu, smýšlení a zvyky, seznámily se s běžným životem místních obyvatel. Zároveň některé čtenářky uvádí, že se tak dozvěděly hodně o islámu, muslimských tradicích a zákonech, udělaly si představu o islámských národech a zemích. V mnoha prrípadech se jednalo o prostředí, které do té doby považovaly za neznámé. Pro některé autorky komentářo̊ se přcčtením dané knihy změnil pohled na prostředí, které popisuje, dříve se jednalo jen o místo na mapě. Současně si některé čtenářky, dle svých komentářů, po přečtení knihy vyhledávaly informace o dané zemi, dále se o tematiku zajímaly. Jedna z komentujících si, dle svých slov, poté přečetla korán, ale pouze jako knihu. Informační hodnota je zvyšována tím, že se často jedná o životní příběhy, dle komentujících, pravdivé, skutečné a autentické.

Nejsilnější téma bylo srovnávání poměrů a údělu hrdinky v knize s životem v České republice. Komentující si po přečtení dané knihy váží života v českém prostředí. Mají, dle jejich slov, štěstí, že žijí v „naší kultuřre. Ačkoliv ani u nás nemusí být situace úplně dokonalá. Často je právě život v ČR oceňován $\mathrm{z}$ hlediska postavení žen. „Po prečtení knihy musí být skoro každá žena ráda, že žije aspoň tady, v České republice“.

Komentáře pod knihami slouží $\mathrm{k}$ ohodnocení knihy a také k možným doporučením / nedoporučením díla ostatním čtenářům. Komentující knihy často doporučují a nejčastěji se odvolávají právě na ostatní ženy. „Doporučuji přečíst všem ženám, abychom se zamyslely nad tím, jaké máme štěstí, že žijeme ve svobodné zemi a o svém životě si můžeme rozhodnout sami“. 
Právě svoboda je komentujícími vnímána jako nejcennější hodnota, kterou oproti knižním hrdinkám mohou zažívat. Objevuje se zde také apel, aby tento typ knih lidé četli více a aby se této problematice obecně věnovalo více pozornosti. Špatné postavení žen v islámských zemích je téma, které je pro komentující důležité. $\mathrm{V}$ několika prrípadech knihu čtenářky doporučovaly jako povinnou četbu. Jako jeden $\mathrm{z}$ důvodů komentující uvádí "psaní vlastních př́běhů je jedním ze způsobů žen, jak proti absolutní a nepochopitelné nadvládě mužů bojovat“. Autobiografické příběhy, které v sobě, dle komentujících, skrývají opravdovost, mají potenciál situaci v tamních oblastech změnit. $Z$ jiného úhlu pohledu komentáře poukazovaly na změnu nás samotných, tedy změnu být po přečtení knihy lepšími lidmi.

Kultura a život v muslimských zemích jsou pro komentující vzdálené (někteří kvitují slovy „naštěstí"), neuchopitelné a mnohdy také nepochopitelné. Hromadně odsuzují násilí, které na hlavních postavách páchají jejich mučitelé (at' už se jedná o konkrétní postavu nebo o abstraktní entitu - režim). $\mathrm{V}$ některých př́padech se jedná o celkové opovržení tamní společností, která je necivilizovaná (oproti západnímu světu), nebo dokonce celého islámu jakožto náboženství - „Opět kniha z prostředí islámu a opět strašné". Mezi komentujícími se tak formuje obraz utiskovaných islámských žen jako obecné skupiny, jejíž v západních zemích viditelná část je jen pomyslnou špičkou ledovce - „Věřim, že tak otřesné věci se stávají $v$ dnešní době v těchto zemích 90ti \% žen“, „nejstrašnější je pomyšlení, že ten príběh je o ženě, která měla štěstí. A kolik jich ho nemělo či nemá?". V jiných prrípadech se v komentárích objevuje relativizace související s prričítání viny konkrétním jedincům nebo skupinám - „Autorka, byt' sama konvertovala ke křestanství, neodsuzuje islám jako takový, jen jeho „špatné pojetí. Odsuzuje nepravosti, které se dějí v komunitách, odvolávající se mnohdy falešně na Korán. Nicméně ne všechno, co se v této knize děje, souvisí pouze s náboženským vyznáním.". A zasazení do širšího historického a sociálního kontextu „Patrně proto, že měla autorka možnost se podrobně seznámit s blízkovýchodními reáliemi, zasadila tam i děj románu. Jinak se hlavní linie - tyranie, domácí násilí - táhne dějinami i kulturami odnepaměti."

U knih, které pojednávají o neštastném příběhu ženy Evropanky, jež se vdala za muže cizince pocházejícího z muslimské země, se v komentárích objevuje varování všech žen před sňatky s muži cizinci, muži z jiné kultury nebo Araby a muslimy. „Príběh, který by mohl pomoct otevřit oči ženám ženoucím se do nerovného sňatku dvou rozdílných kultur a náboženství, „je to i výstraha pro zamilovaná dèvčata do mužů vychovaných $v$ jiném světěc. Zároveň na tyto prríběhy reagují lidé v komentářích spíše odsouzením hlavní ženské postavy, s tím, že si za své trápení mohla sama. „autorky mi líto není, má co chtěla, byla naivní a možností vrátit se domů měla až dost... Co čekala? Může být ráda, že žije. "V takovýchto komentárích se projevuje stereotypní pohled na sňatky s cizinci, muslimy, který nemohou než končit tragicky. V komentárích se objevuje předpoklad sdíleného stereotypu mezi všemi ženami. Tudíž všechny ženy mají vědět, co je pro takový sňatek typické.
Komentující mají také často určitou představu, jak se tento typ románu vyvíjí, jaké prvky se v něm objevují a jak většinou končí - „Příběh klasicky arabský, dívka donucena se vdát za staršího muže...", "jinak mi kniha pripadá jako klasika - Arab a Evropanka. Nepopírám, že kniha má několik zajímavých zvratů, ale jinak je to nalajnované jako obvykle“. Komentovaná kniha není často knihou první s touto tematikou - „jedna z těch lepších knižek, které se zabývají problematikou práv muslimských žen".

Pokud kniha nesleduje očekávanou strukturu, nalezneme v komentárích dva typy reakcí. Prvním typem je zklamání komentujících, jelikož kniha nesplnila očekávání a situace v knize se odchylují od „normálního“ schématu - „Knižka mě hodně zklamala. Čekala jsem príběh o Evropance, která se chcel musí stát arabskou ženou. Pritom je to príběh o Evropance, která se přistěhovala do arabského státu... Některé věci by se tam odehrát ani nesměly a ona je přesto může... Podle mne, se to nedá brát vážně“. Druhým typem reakce je naopak ocenění, že se kniha nedrží klasické osnovy a přináší nové informace - „Tak jsem čekala, že to bude dalši knížka $z$ rady trpících Evropanek, co si vzaly Araba a ted' pláčou, že jim vzal děti... ale tahle knížka má o mnoho víc“.

Termíny arabské ženy nebo arabský svět jsou komentujícími $\mathrm{v}$ některých případech přisuzovány i zemím ne arabským. Ačkoli se děj odehrává např. v Afganistánu, v komentáři pod knihou se objevuje "Př́běh klasicky arabsky“" nebo „Poutavý přiběh, kdy má každý možnost seznámit se nenásilnou formou s dèjinami Afganistánu a s postavením žen v arabských státech". Dochází zde $\mathrm{k}$ arabizaci islámského světa a tím $\mathrm{k}$ podpoře jeho homogenního chápání.

Knihy také některé komentující utvrzují v tom, co už věděly předtím, v pohledu na trpící muslimské ženy jako nevinné oběti - „To jak autor popisuje postavení arabských žen, ta bezmoc, hlad, násilí, bití - šel mi mráz po zádech. Nechápala jsem... věděla jsem, že to tak v těchto kulturách chodí, ale..."

Pro komentující je v některých prrípadech znepokojivé a nepochopitelné, že se na útlaku žen podílí také ostatní ženy (především matky). Tedy že jako viníci nevystupují pouze muži. $\mathrm{V}$ těchto př́padech lze pozorovat narušení schématu, které se váže $\mathrm{k}$ takovémuto typu príběhů - agresor je muž, obět je žena. "Nejhorši je, že tou zlou osobou je její vlastní matka a sestra, a ne jak to často bývá otec či bratři. “ Současně jsou tyto ženy agresorky vnímány skrze optiku vyšších pravidel/ tradic, ve kterých jsou uvězněny „nejsmutnější na věci je to, že to samy ženy v první řadě udržují tyhle blbé rituály (pozn. ženská obřízka), které jsou násilím na dètech". Jsou pasivní a podrobené - „ženy vưbec nemají tendenci držet jedna při druhé. Spíše dochází k situaci, kdy ženy mlčky akceptují svou roli ve společnosti, přizpiosobí se očekáváním společnosti, zatvrdí se (či zahořknou) a potom striktně vyžadují stejné chování i od ostatních žen. " Nebo jsou komentujícími ženy páchající násilí na ženách vnímány jako oběti mužů (respektive mužského světa) - „nejstrašnější mi připadá, že v mnoha prípadech jsou to jiné ženy, které se na týrání podílejí - je to snad jako s mazáctvím nebo to souvisís tím, že se snaží být s tyrany raději než s týranými, aby taky nepřišly na řadu“. 
Pro některé komentující by bylo prolomení této přičítané pasivity žen východisko, jak odstranit páchané násilí - jinak řečeno, kdyby se ženy odmítaly podílet na páchání násilí. „V každém prípadě si myslím, že kdyby ženy v tom podivném světě jakkoliv, ale masově, odmitly toto násilí, muselo by skončit". Muslimské ženy jsou v komentárích tedy chápány jednak jako oběti, a to vždy společnosti (která může vystupovat skrze rodinu, manžela, režim apod., jež jednají podle určitých zásad). Jednak jsou ženy pomocnice v páchání násilí, ale i v tomto př́padě leží vina často na straně mužů, tedy ženy jsou zde opět určitými obětmi.

Kromě výše představených témat se $\mathrm{v}$ komentárích několikrát objevila kritika přebalů knih. Podle komentujících obálky degradovaly samotný obsah knihy. „Jediná vada pro mě byl přebal knihy, který ve mně zpočátku vzbouzel dojem, že se jedná o literaturu z žánru červené knihovny". Př́běhům je přisuzován vyšší status, než který mají př́běhy označované jako „červená knihovna“ či „laciná harlequin“.

\section{DISKUSE}

České čtenářky a čtenáři pocitují výraznou dichotomii mezi západním a islámským světem, umocňovanou přirozeně i exotickými reáliemi př́běhů. Tragické př́běhy žen (bez ohledu na jejich pravdivost či smyšlenost) se velice často zobecňují na typický ženský úděl v islámských zemích, které jsou takřka démonizované. Oproti tomu je mnohokrát vyzdvihováno „štěstí č čtenářek v podobě jejich vlasti v (naopak idealizovaném) prostředí české kotliny. Zajímavé je naprosté opomíjení vlastní, a to i relativně nedávné, historie. Př́běhy odpozorované z českého a moravského venkova 19. století a reprodukované dobovými spisovateli, poskytují překvapivě, i co se autenticity týče, velice blízké analogie „islámským novelám“. At” už jde o vynucené sňatky končící katastrofou (Maryša bratř̌í Mrštíků), nebo dokonce zabíjení „nevhodně narozených“ dětí za účelem výhodného sňatku dcery (Její Pastorkyña Gabriely Preissové z prostředí Moravského Slovácka). Zvyk nošení šátků ve venkovském prostředí přetrvávající u starších žen dodnes nemá už ani smysl zmiňovat. Na tuto zvláštní nekritičnost poukazuje např́ílad S. Komárek: „Evropská společnost se muslimů děsí, v zásadě ale představují v radè aspektů její stínový obraz, byt'se jejich societ a svou strukturou neliši zásadně od té naši préd sto lety. "(Komárek 2010). Zatímco vymezování se vůči vlastní „,barbarské" historii je dnes nereálné a na vlastní minulost nahlížíme s jakousi „skanzenovitou“ nostalgií, měŕítka pro hodnocení „cizi“ kultury jsou nastavena zcela jiným způsobem.

\section{ZÁVĚR}

„Ženská muslimská literatura“ je v českém prostředí (stejně jako $\mathrm{v}$ evropském $\mathrm{i}$ americkém) atraktivním a žádaným artiklem. K žánru čtenáři přistupují většinou nekriticky jako $\mathrm{k}$ autentickým príběhům, skýtající zdroj relevantních informací jak o reáliích dané země a regionu, tak i o rodinných vztazích, o kultuře a mentalitě tamních obyvatel.

Knihy vyvolávají u komentujících především emoce, pro čtenářky / čtenáře jsou čtivé a poutavé. Příběhy u komentujících nejčastěji potvrzují jejich negativní stereotypní představu, př́ípadně ji modifikuje (jak přesně se $\mathrm{v}$ komentárích neobjevuje). Ženy v muslimských zemích jsou většinou v komentářích vnímány jako homogenní masa, která je obětí svého prostředí (rodiny, režimu) na druhou stranu jsou hlavní postavy heroizovány. Viktimizace se dotýká všech žen, dokonce i těch, které se na páchání násilí podílejí. Jako pachatele komentující na obecnější úrovni označují společnost, se svými tradicemi, kulturou a náboženstvím, jež je nepřátelská vưči všem ženám. $\mathrm{Na}$ konkrétnější úrovni se jedná převážně o muže a rodinu oběti, která může být tvořena i dalšími ženami. V komentářích se objevuje stereotypní vnímání mezietnického sňatku, který podle očekávání končí špatně. Současně je vyslovován předpoklad, že všichni by měli tento stereotyp sdílet (normativita stereotypu). Výrazným rysem je i vnímání islámského světa čtenářkami / čtenáři jako monolitu, nejčastěji je redukován na arabskou kulturu.

V několika př́ípadech se setkáváme i s kritikou přebalů knih, jež v komentujících vzbuzují dojem, že se jedná o červenou knihovnu, ačkoli tomu tak dle nich není a knihám je naopak přisuzován vy̌šší status.

Jak vyplývá z komentářů, jedná se rozšířený a etablovaný žánr, který mnohdy evokuje u komentujících představu jasně dané struktury přiběhu, potažmo i konec. Výjimečné nenaplnění tohoto očekávání (dobrý konec) je někdy komentován rozpačitě. Ze zkoumaných komentářů vyplývá, že „ženská muslimská literatura" ovlivňuje určitým způsobem své publikum a modifikuje do jisté míry vnímání islámu a muslimů (jak muslimských žen, které jsou oběti, tak muslimských mužů jakožto pachatelů, tak islámu jako nepřátelské sociální prostředí). Avšak s přihlédnutím ke zkoumanému vzorku a jeho limitům je nutné konstatovat, že vždy záleží na konkrétním čtenáři a čtenářce a jejich osobních charakteristikách, jak se $\mathrm{k}$ danému tématu postaví. Zda přijmou knihu jako přesný obraz reality a jedinou univerzální normou pro islámský svět, anebo ho budou vnímat jako to, čím je, tedy především literárním dílem $s$ větší či menší mírou autorské licence a jistě nepokrývající všechny aspekty postavení žen v muslimských zemích.

\section{LITERATURA}

Fotouhi, S. (2012): Self-orientalization and reorientation: a glimpse at Iranian Muslim women's memoirs. Dostupné on-line: http://www.unisa.edu.au/ Documents/EASS/MnM/csaa-proceedings/Fotouhi.pdf , 4.8.2014.

Görikasel, B. - McLarney, E. (2010): Muslim Women, Consumer Capitalism, and the Islamic Culture Industry. Journal of Middle East Women's Studies, $6 / 3,1-18$.

Huggan, G. (2001): The Post-Colonial Exotic: Marketing the Margins. London-New York: Routledge.

Janků, T. (2013): Paní učitelko, proč máte ten šátek? Aneb žena v islámu. P̌̌ES: Čtvrtletník o migraci a lidských právech, X/31, 16-18.

Jelodar, E. Z. - Yusof, N. M. - Hashim, R. S. - Hamdan, S. I. - Raihanah, M. (2013): Orientalization through Paratexts: The Covers of Muslim Memoirs. Asian Social Science, 9/13, 169-176. 
Jelodar, E. Z. - Yusof, N. M. - Hashim, R. S. (2014): Muslim Women's Memoirs: Disclosing Violence or Reproducing Islamophobia? Asian Social Science, 10/14, 215-223.

Kahf, M. (1999): Western Representations of the Muslim Woman. Texas: University of Texas Press.

Komárek, S. (2010): My, evropští masochisté. Dostupné on-line: http://blog. aktualne.cz/blogy/stanislav-komarek.php?itemid=11338, 4.8.2014.

Pazargadi, L. (2010): Marketing „Honor Killing“ Memoirs: Confronting Western Depictions of Muslim Women. Dostupné on-line: http://www. escholarship.org/uc/item/57k2604f\#page-1, 4.8.2014.

Whitlock, G. (2007) Soft weapons: autobiography in transit, University of Chicago Press, Chicago.

Zine, J. (2002): Muslim Women and the Politics of Representation. American Journal of Islamic Science, 19/4, 1-22.

\section{AUTOŘI}

Čermáková, Eva (29. 7. 1980, Brno), vystudovala archeologii a antropologii na Filozofické a Prrírodovědecké fakultě Masarykovy univerzity $\mathrm{v}$ Brně. $\mathrm{V}$ současné době pracuje jako výzkumník společnosti SocioFactor, s.r.o. a externě přednáší na Katedře sociologie, andragogiky a kulturní antropologie na Univerzitě Palackého v Olomouci. Zabývala se genderovou problematikou v prehistorických společnostech a v současnosti se podílí na výzkumu etablování muslimské menšiny v České republice.

Kontakt: Mgr. Eva Čermáková, Ph.D., SocioFactor s.r.o., Gorkého 11, Brno, 602 00; e-mail: cermakova@sociofactor.eu.
Linhartová, Lenka (14. 3. 1988, Tábor), vystudovala obor sociologie na Fakultě sociálních

studií Masarykovy univerzity v Brně. V roce 2013 studium úspěšně ukončila a získala titul Mgr. V současné době působí jako výzkumná pracovnice ve společnosti SocioFactor s.r.o., která se zabývá aplikovaným výzkumem - realizuje jak kvalitativní, tak kvantitativní šetření.

Kontakt: Mgr. Lenka Linhartová, SocioFactor s.r.o., Gorkého 11, Brno, 602 00; e-mail: linhartova@sociofactor.eu.

Topinka, Daniel (25. 5. 1971, Opava) vystudoval sociologii a religionistiku na Filozofické fakultě a Fakultě sociálních studií na Masarykově univerzitě v Brně, doktorskou práci na téma integrace muslimů do české společnosti obhájil na Univerzitě Palackého v Olomouci $\mathrm{v}$ roce 2008. V současnosti působí jako odborný asistent na Katedře sociologie, andragogiky a kulturní antropologie Filozofické fakulty Univerzity Palackého v Olomouci a ve výzkumné společnosti SocioFactor. Zabývá se problematikou sociální inkluze a exkluze, sociologií a antropologií migrace, náboženstvím ve veřejném prostoru, etnickými a religiózními identitami, emickou perspektivou okrajových a marginalizovaných skupin a islámem.

Kontakt: PhDr. Daniel Topinka, Ph.D. , SocioFactor s.r.o., Daliborova 631/22, Ostrava - Mariánské Hory, 709 00; e-mail: topinka@ sociofactor.eu. 